CHAPTER 5

\title{
Provinciae et civitates ecclesiis plenae. Transformation of the civitates Indorum in the Apocryphal Acts and the Liturgical Commemoration of the Apostle Thomas
}

\author{
Els Rose
}

The liturgical practices evident in the apocryphal Acts of Thomas have intrigued many scholars in recent decades because of their unique character ${ }^{1}$ as well as their singular approach to doctrinal matters such as the Holy Trinity and the sacraments. Among those scholars, Gerard Rouwhorst occupies a prominent position, primarily thanks to his analyses of Eucharistic and baptismal rituals, the Trinity, and hymns in the Acts of Thomas. ${ }^{2}$ Rouwhorst's motivation to study the written account of such ancient Christian rituals is to demonstrate how the apocryphal Acts in general, and those of Thomas in particular, give a diverse and fluid impression of the earliest ages of Christianity,

1 Thus C. Johnson, "Ritual epicleses in the Greek Acts of Thomas," in The Apocryphal Acts of the Apostles, Harvard Divinity School Studies, ed. F. Bovon et al. (Cambridge, MA: Harvard University Center for the Study of World Religions, 1999), 182: "The epicleses of the Acts of Thomas remain unique among these early church traditions".

2 G.A.M. Rouwhorst, "Hymns and Prayers in the Apocryphal Acts of Thomas," in Literature or Liturgy? Early Christian Hymns and Prayers in their Literary and Liturgical Context in Antiquity, ed. C. Leonhard and H. Löhr (Tübingen: Mohr Siebeck, 2014), 195-212; id., "Faire mémoire par un geste: La fraction de pain," in Faire mémoire. L'anamnèse dans la liturgie, Conférences SaintSerge LVIe Semaine d'Études liturgiques. Paris, 29 juin-2 juillet, 2009, ed. A. Lossky and M. Sodi (Città del Vaticano: Libreria editrice Vaticana, 2011), 75-86; id., "L'usage et le non-usage du vin," in Rites de communion, Conférences Saint-Serge Lve Semaine d'Études liturgiques. Paris, 23-26 juin, 2008, ed. A. Lossky and M. Sodi (Città del Vaticano: Libreria editrice Vaticana, 2010), 22941; id., "Die Rolle des heiligen Geistes in der Eucharistie und der Taufe im frühsyrischen Christentum," in Liturgie und Trinität, ed. B. Groen and B. Kranemann (Freiburg im Breisgau: Herder, 2008), 161-84; id., "La célébration de l'eucharistie selon les Actes de Thomas," in Omnes circumadstantes. Contributions towards a History of the Role of the People in the Liturgy, ed. Ch. Caspers and M. Schneiders (Kampen: Kok, 1990), 51-77. See also the work by Susan Myers on the invocation of the holy Spirit in the Acts of Thomas, most recently "Antecedents of the Feminine Imagery of the Spirit in the Acts of Thomas", Apocrypha 26 (2015): 103-118. For further references, see Rouwhorst, "Hymns and Prayers," 195.

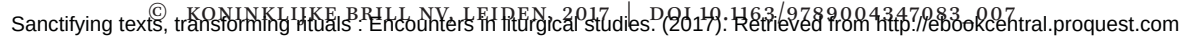
Created from uunl on 2019-07-26 04:43:15. 
fluid in the sense that, as he phrases it, 'les lignes de démarcation entre l'orthodoxie et l'hétérodoxie étaient beaucoup plus floues qu'elles ne le seraient plus tard, par example après les grandes conciles des quatrième et cinquième siècles'. ${ }^{3}$

In the present contribution, the relation between the apocryphal Acts of Thomas and liturgical practices is at the centre of attention, but from a different angle. My investigation turns to the Latin transmission of the Acts of Thomas and inverts the research direction described above. It centres the question as to how the apocryphal Acts, condemned by some patristic authors as too close to heretical milieus but transmitted as valuable sources on the first Christian communities and their leaders, took firm root in the liturgical commemoration of the apostles as founders of these communities. ${ }^{4}$ The prayers for Mass as they are transmitted in the earliest Latin sacramentaries ${ }^{5}$ are my point of departure in the analysis of apocryphal material in liturgical texts. A general survey of relevant places and sources of liturgical commemoration is followed by an analysis of the selected themes and elements from the apocryphal Acts that play a role in the liturgical prayers. Then follows a more specific investigation of the way Thomas is depicted as one of the apostolic founders of the Christian Church and how he transformed the 'provinces and cities' ${ }^{\prime}$ of

3 Rouwhorst, "La célébration de l'eucharistie," 55.

4 On the variety of opinions with regard to the apocryphal Acts of the apostles in the work of Latin authors between the fourth and early thirteenth centuries, see E. Rose, Ritual Memory. The Apocryphal Acts and Liturgical Commemoration in the Early Medieval West (c. 500-1215), Mittelalterliche Studien und Texte 40 (Leiden: Brill, 2009), 23-78. On the continuous sceptical approach to the apocryphal Acts, particularly the Acts of Thomas, also in modern times, see Die alten lateinischen Thomasakten, ed. K. Zelzer (Berlin: Akademie-Verlag, 1977), xi. On the importance of the apocryphal Acts as foundation myths, see Écrits apocryphes chrétiens I, ed. F. Bovon and P. Geoltrain (Paris: Gallimard, 1997), xxxxix; F. Bovon, "La vie des apôtres. Traditions bibliques et narrations apocryphes," in Actes apocryphes des apôtres, ed. F. Bovon et al. (Geneva: Labor et Fides, 1981), 146-47; Rose, Ritual Memory, 41-42 and 293-94.

5 In the early medieval West each officiant in the liturgy of Mass (and, mutatis mutandis, the liturgy of Hours) had his own book with relevant texts, music and ritual instructions. The book for the priest or bishop was the sacramentary, containing the presidential prayers for the Masses of Sundays and feast-days. I surveyed the prayers for Thomas' feast-day (his natale on 21 December and the translation of his relics, celebrated in North-Italy on 3 July) from the collection of Eucharistic prayers by Moeller: Corpus orationum, CCSL 16o-16oM, ed. E. Moeller et al. (Turnhout: Brepols, 1992-2004); Corpus praefationum, CCSL 161, 161A-161D, ed. E. Moeller (Turnhout: Brepols, 1980-81); Corpus benedictionum pontificalium, CCSL 162, 162A-162C, ed. E. Moeller (Turnhout: Brepols, 1971-79).

6 Cf. Passio Thomae (BHL 8136), c. 21, where Thomas proclaims to King Gundafor after he has used the king's money for charity and conversion: Ecce et provinciae vestrae et civitates vestrae ecclesiis plenae sunt. Zelzer, Die alten lateinischen Thomasakten, 16.

Sanctifying texts, transforming rituals : Encounters in liturgical studies. (2017). Retrieved from http://ebookcentral.proquest.com Created from uunl on 2019-07-26 04:43:15. 
India, where he was sent to accomplish his mission work, into a Christian community. Now I shall first briefly summarise the apocryphal Acts of Thomas in their Latin transmission.

\section{Virtutes Thomae: The Apocryphal Acts of Thomas in their Latin Transmission}

The Latin transmission of the apocryphal Acts of Thomas is split in two fairly distinctive traditions, labelled by the most recent modern editor, Klaus Zelzer, as De miraculis beati Thomae apostoli (BHL $8140^{7}$ ) and Passio sancti Thomae apostoli (BHL 8136). The former text is, according to Zelzer, much closer to the Greek Acts, ${ }^{8}$ while the Passio is much more prominent in the liturgical prayers as we shall see shortly. Zelzer considers the Miracula text in its supposedly original version as the most original Latin transmission, composed independently from the Passio. However, the form in which we find the Miracula in the manuscripts must be a younger version that has been partly conflated with the Passio, as is shown by one passage that both text traditions have in common (c. 51-6o). ${ }^{9}$ The date of origin and the authorship of the Latin Acts of Thomas are difficult to establish in a definitive way. Zelzer opts to date the Latin rewriting to the second half of the fourth century. ${ }^{10} \mathrm{He}$ is less confident when it comes to indicating a named author, although he is inclined to reject the suggestion made by Lipsius, and followed by Bonnet, that Gregory of Tours was responsible for the Latin text. ${ }^{11}$

7 BHL refers to Bibliotheca hagiographica latina antiquae et mediae aetatis (Brussels: Société des Bollandistes, 1898-1901).

$8 \quad$ Zelzer, Die alten lateinischen Thomasakten, xxiii.

$9 \quad$ Zelzer, Die alten lateinischen Thomasakten, xxiv, where Zelzer explains that this passage is more organically inserted in the Passio than in De miraculis. Zelzer lists the relevant manuscripts in ibid., xlv-xlviii and discusses those copies used in the edition on the following pages, xlix-liv. See for additional manuscripts E. Rose, "Abdias scriptor vitarum sanctorum apostolorum? The "Collection of Pseudo-Abdias" reconsidered," Revue d'histoire des textes n.s. 8 (2013): 227-68. The appendix to the latter article makes clear that, within the context of a series of texts for all apostles, the transmission of the Latin Acts of Thomas differs by region: BHL 8140 is mainly found in manuscripts that have their origin in South Germany/ Bavaria (the monasteries of Skt Gall, Regensburg; further Bamberg and Salzburg), WestGermany (Weissenburg) and North Italy (Aquileia), while monasteries and cathedrals in the Frankish regions of Burgundy, Paris and Angers mainly transmit BHL 8136.

$10 \quad$ Zelzer, Die alten lateinischen Thomasakten, xxiv-xxvi.

11 Zelzer, Die alten lateinischen Thomasakten, xxvi-xxix, confirmed by A. De Santos Otero, "Jüngere Apostelakten," in Neutestamentliche Apokryphen in deutscher Übersetzung. 6. Auflage der von Edgar Hennecke begründeten Sammlung, vol II: Apostolisches, Apokalypti- 
The Latin narrative of the Virtutes Thomae, a term I use to indicate the transmission of Passio and Miracula together, ${ }^{12}$ follows the Greek Acts in its tripartite structure. It tells the story of the apostle Thomas, who is sent to India by Christ in person. The missionary work of the apostle in this remote area concentrates largely on three episodes. The first section describes Thomas' departure for India in the company of Abbanes, an envoy of the Indian king Gundafor. Abbanes has been sent by the king to find an architect to build him a new palace. At the market, Thomas is recommended to him by Christ as a very apt candidate. Together, they travel back to India, and Abbanes is surprised by the miraculous speed by which they travel. Upon their arrival in India, but before they travel on to Gundafor's court, Thomas and Abbanes attend a wedding, and Thomas converts the bridal couple to a chaste life. The second part elaborates on Thomas' main assignment in India: to design and build a palace for King Gundafor. The king first provides Thomas with large sums of money to accomplish this task and then leaves for a period of two years. During his absence, Thomas spends all the king's money on charity and the building of churches. Upon his return, the king discovers that his will has been ignored and throws Thomas in prison. Then the king's brother, Gad, falls ill and, near death, is taken to heaven where he sees in a vision the real palace that Thomas has produced: a heavenly palace of precious stones in which angels provide a guided tour. Upon his return from heaven, Gad pleas for Thomas' release and his request is fulfilled. The brothers fight among themselves about who may possess the heavenly palace, so Thomas invites the two of them to Baptism so that they can both become 'participants in the eternal kingdom'. ${ }^{13}$ Then follows a series of chapters in which Thomas goes around preaching and healing. The third section is located in yet another part of India and relates Thomas' friendship with Mygdonia, the wife of the ruler Charisius, a relative of king Mesdeus. Mygdonia converts and becomes Thomas' disciple, to Charisius' great displeasure. Here, the encratitic character that the Acts of Thomas are known for is at the centre of the narrative. The apostle's preaching of chastity, to which Mygdonia and other highborn women in her circle willingly lend an

sches und Verwandtes, ed. W. Schneemelcher (Tübingen: Mohr Siebeck, 1997), 410-11. I reconsidered Zelzer's rejection and came to a more positive consideration of Gregory's possible role, primarily based on the prologue of BHL 8140 which indicates that Gregory was probably not the author of the text but might have played a role as its reviser; see E. Rose, "Virtutes apostolorum: Origin, Aim, and Use", Traditio 68 (2013): 77-78.

12 On terminology, see Rose, “Virtutes apostolorum: Origin, Aim, and Use," 58.

13 Passio Thomae, c. 21: Parati ergo estote ut sanctificemini ut loti aqua fontis aeterni efficiamini perpetui regni participes. Zelzer, Die alten lateinischen Thomasakten, 16. 
ear, is, together with Thomas' refusal to sacrifice to the sun god, the immediate cause of the apostle's martyrdom. ${ }^{14}$ Themes

\subsection{Rome and Eighth-Century Frankish Gaul}

Although a church dedicated to Thomas is among the earliest apostolic tituli in the city of Rome, ${ }^{15}$ his feast is lacking in the oldest sacramentaries traditionally linked to the liturgical practice of Rome, the Sacramentarium Veronense ${ }^{16}$ and the Sacramentarium Gregorianum Hadrianum. A praefatio for Thomas is found only in the early ninth-century supplement to the Gregorian Sacramentary, which provided material to make the book from Rome suitable for use in a Frankish context. In Frankish Gaul as well, the liturgical commemoration of Thomas was a relatively late development. The apostle does not appear in the Gallican Mass books before the eighth century. This in itself is remarkable, because relics of the apostle had arrived in Gaul at the end of the fourth century, as the Sermo de laude sanctorum of Victricius of Rouen reports: hic [invenietis] Andream, hic Thomam. ${ }^{17}$ While the cult of Andrew developed in many parts of Gaul from that moment onwards, and a liturgical veneration of this apostle is attested in the Gothic Missal and the Irish Palimpsest Sacramentary, ${ }^{18}$ no such

14 For a more elaborate and synoptic survey of Passio, Miracula and the Greek Acts, see Zelzer, Die alten lateinischen Thomasakten, xiii-xxii; for the ancient (Greek and Syriac) versions, see A.F.J. Klijn, The Acts of Thomas. Introduction, Text, and Commentary, Supplements to Novum Testamentum 108 (Leiden-Boston: Brill, 2003), 4-6 and 10-14.

15 The Liber pontificalis mentions the building of a chapel for this apostle by pope Symmachus (498-514); V.L. Kennedy, The Saints of the Canon of the Mass (Città del Vaticano: Pontificio Istituto di Archeologia Cristiana, 1938), 104; Liber pontificalis I, MGH GPR I, ed. Th. Mommsen (Berlin: Weidemann, 1898), 123.

16 Although most recent scholars doubt the relation between this collection of Masses with Rome: Ph. Bernard, Transitions liturgiques en Gaule carolingienne. Une traduction commentée des deux “lettres” faussement attribuées à l'évêque Germain de Paris (Paris: Hora decima, 2008), 16.

17 Victricius of Rouen, De laude sanctorum, c. 6., CCSL 64, ed.J. Mulders and R. Demeulenaere (Turnhout: Brepols, 1985), 78.

18 Missale Gothicum, cCSL 159D, ed. E. Rose (Turnhout: Brepols, 2005), 265-66. On the early cult of Andrew in Frankish Gaul, see E. Ewig, "Die Kathedralpatrozinien im römischen und fränkischen Gallien," in Spätantikes und fränkisches Gallien. Gesammelte Schriften (1952-1973), ed. H. Atsma (Munich: Artemis Verlag, 1979), vol. 2, 287-89. 
cult or liturgical commemoration fell to the apostle Thomas in this region. ${ }^{19}$ A Mass for the natale on 21 December (XII Kalendas Ianuariis) is found for the first time in the mid eighth century, in the Old Gelasian Sacramentary. This collection of Masses, entitled Liber sacramentorum romanae ecclesiae, is preserved in a single codex copied in Frankish Gaul around 750. ${ }^{20}$ The commemoration of Thomas on 21 December was continued in the Frankish eighth-century Gelasian sacramentaries, a new type of sacramentary that combined material from the Old Gelasian and Gregorian sacramentaries with structural elements and prayer texts taken from the Gallican sacramentaries. A considerable number of manuscripts transmitting this kind of sacramentary are preserved from the final decades of the eighth and the beginning of the ninth centuries. ${ }^{21}$

The prayers for Thomas in the eighth-century Gelasian sacramentaries have much in common with the Mass ordo in the Old Gelasian Sacramentary. ${ }^{22}$ This includes specific emphasis on Thomas as a powerful patron and a model of faith, whose intercession is prayed for to protect the faithful who celebrate

19 A church, monastery or altar dedicated to Thomas appears only rarely in Ewig's gründliche surveys; see id., "Der Petrus- und Apostelkult im spätrömischen und fränkischen Gallien," in Spätantikes und fränkisches Gallien, vol. 2, 348; id., "Die Verehrung orientalischer Heiliger im spätrömischen Gallien und im Merowingerreich”, in Spätantikes und fränkisches Gallien, vol. 2, 398: "Anders stand es mit dem Kult des Apostels Thomas und des Evangelisten Lucas, die zwar zur ambrosianischen Heiligenreihe gehörten, aber doch wohl erst später und nur in bestimmten Orten Galliens Eingang fanden". Thomas' cult seems to be confined to Arles (see also ibid., 406, 408). The seventh-century Irish Palimpsest Sacramentary, SB Munich, Clm 14429, is famous for its inclusion of an epiklesis derived from the Acts of Thomas in the Ordo missae circumcisionis, ed. A. Dold and L. Eizenhöfer, Das irische Palimpsestsakramentar im CLM 14429 der Staatsbibliothek München (Beuron: Beuroner Kunstverlag, 1964), 43-47. On this use of the Acts of Thomas in a Gallican liturgical book, which is beyond the scope of the present article, see S. Brock, "Invocations to/for the Holy Spirit in Syriac Liturgical Texts: Some Comparative Approaches," in Comparative Liturgy Fifty Years after Anton Baumstark (1872-1948), ed. R.T. Taft and G. Winkler (Rome: Pontificio Istituto Orientale, 2001), 380; J.H. Crehan, "Eucharistic Epiklesis: New Evidence and a New Theory," Theological Studies 41 (1980): 698-712; J.K. Henry, "The Acts of Thomas as Sacred Text," in Sacra Scriptura. How "NonCanonical" Texts Functioned in Early Judaism and Early Christianity, ed. J.H. Charlesworth et al. (London-New York: Bloomsbury, 2014),167.

20 C. Vogel, Medieval Liturgy. An Introduction to the Sources, transl. W. Storey and N. Rasmussen (Washington DC: The Pastoral Press, 1986), 64-65.

21 Vogel, Medieval Liturgy, 70-76; Y. Hen, The Royal Patronage of Liturgy in Frankish Gaul to the Death of Charles the Bald (877) (London-Rochester, N.Y: Boydell Press, 2001), 57-61.

22 Liber sacramentorum Romanae aeclesiae ordinis anni circuli (Cod. Vat. Reg. lat. 316/Paris Bibl. Nat. 7193, 41/56) (Sacramentarium Gelasianum), ed. L.C. Mohlberg (Roma: Herder, 1968), 166. 
the Eucharist in his honour. The younger Gelasiana add one or two prayers in comparison to the three in the Old Gelasian. Most representatives contain an additional praefatio, while the oldest Frankish manuscript, the Gellonensis, also adds a prayer after communion, using the original post communionem of the Old Gelasian as a closing prayer super populum. The references to Thomas in these Frankish prayers likewise concern the saint's patronage and the protective power of his intercession. The Frankish praefatio that is added in the younger Gelasiana, which is also present in the Supplement to the Gregorianum Hadrianum, is the only text that pays more specific attention to Thomas' apostolic qualities:

VD aeterne deus. Qui ecclesiam tuam in apostolicis tribuisti consistere fundamentis, de quorum collegio beati Thomae apostoli tui solemnia celebrantes, tua domine praeconia non tacemus. Et ideo cum angelis. ${ }^{23}$

It is truly worthy [that we praise you] eternal God. For you have granted your Church to stand firmly on the foundations laid by the apostles, of whose collegium we celebrate the holy feast of your blessed apostle Thomas while we cry out your praises, O Lord. And therefore, with the angels [...]

This prayer reveals the importance attached to the apostolic foundation of the Church in the late eighth-century Frankish world, to which the increase of manuscripts transmitting the Latin rewritings of the apocryphal Acts of the Apostles in the same period and region likewise testifies. ${ }^{24}$ Yet the text remains fairly general, concentrating on Thomas as one of the collegium of Twelve ${ }^{25}$ and on the role of the apostles as foundation of the Church. We have to search outside Frankish Gaul for specific hagiographic elements and for a more detailed use of the apocryphal Acts in the liturgical prayers for Thomas.

23 Liber sacramentorum Gellonensis, 1759, CCSL 159, ed. A. Dumas and J. Deshusses (Turnhout: Brepols, 1981), 227; see also Liber sacramentorum Engolismensis, 1623, CCSL 159C, ed. P. Saint Roch (Turnhout: Brepols, 1987), 237 and Liber sacramentorum Augustodunensis, 1153, CCSL 159B, ed. O. Heiming (Turnhout: Brepols, 1984), 133; cf. Sacramentarium Gregorianum Hadrianum, Supplementum, 1709, ed. J. Deshusses, Le sacramentaire grégorien. Ses principales formes d'après les plus anciens manuscrits, vol 1: Le sacramentaire, le supplément d'Aniane (Fribourg: Éditions universitaires Fribourg Suisse, 1971), 564.

24 Cf. Rose, "Virtutes apostolorum: Origin, Aim, and Use."

25 Rose, Ritual Memory, 286-91. 


\section{$2.2 \quad$ Milan}

The apostle Thomas was honoured with a special veneration in the Church of Milan ever since Ambrose had brought his relics to the Nazarius basilica around 386 , a feat commemorated on 3 July. ${ }^{26}$ Most manuscripts that represent the Milanese rite contain a Mass order for this Translatio Thomae, usually consisting of five prayers. ${ }^{27}$ Among these five, there is one prayer that includes significantly more details of Thomas' life and character compared to the Gelasian prayers: the praefatio. ${ }^{28}$ In this prayer, themes are chosen not from the apocryphal Acts but from the Gospel according to John. Thomas' doubt and his later faith upon touching Christ's wounds are central. As in other prayer texts referring to these events, ${ }^{29}$ Thomas' initial lack of faith is not evaluated negatively, but considered as a particular sign of celestial grace, bringing to the faithful a remedy for all possible traces of unbelief among them:

Hoc egit miro modo superna clementia, ut discipulus dubitans, dum in magistro suo vulnera palparet carnis, testis verae resurrectionis fieret et in nobis vulnera infidelitatis curaret.

The supreme grace arranged it so that the doubting disciple, when he touched in his Master the wounds of the flesh, became a witness of the true resurrection and healed in us the wounds of infidelity.

We find a more elaborate use of the apocryphal Acts in the liturgical prayers of early medieval Spain.

\subsection{Spain}

Moeller's repertoire of prayers for Mass include various texts from Spanish manuscripts. First, London British Library Add. 30844 combines a Liber misticus (f. 1-172, from Burgos) and a Liber canticorum (f. 173-177, from Castille),

26 Corpus praefationum, 454; Kennedy, Saints of the Canon, 65.

27 I follow the version in the Sacramentarium Bergomense, 989-93: Sacramentarium Bergomense: manoscritto del secolo IX della Biblioteca di S. Alessandro in Colonna in Bergamo, ed. A. Paredi (Bergamo: Monumenta Bergomensia, 1962), 258.

28 Bergomense, 922; also in the sacramentaries of Biasca (928) and Ariberto (762). Corpus praefationum, 951, ed. Moeller, 293.

29 E.g. Liber Mozarabicus sacramentorum, 1340 (Inlatio): Multum namque profuit nobis eius dubietas momentanea, que tam euidenter insinuauit cunctis Redemptoris nostri resurrectio [nem $]$ gloriosam. Ed. M. Férotin, Liber mozarabicus sacramentorum (Paris: FirminDidot, 1912; repr. by A. Ward and C. Johnson, Rome: CLV Edizioni liturgiche, 1995), 611. On this representative of the Old Hispanic rite, see below. 
dating to the tenth or eleventh century. ${ }^{30}$ The Liber misticus contains a Mass order for Thomas. Second, folios 99-101r in Madrid Biblioteca Nacional 494, which were, according to José Janini, added as a separate quire written in a twelfth-century Visigothic script, contain among other things a Mass for St Thomas. ${ }^{31}$ These two sources represent the early medieval Spanish rite that developed from the seventh century onwards with contributions of such authors as Hildefonsus of Toledo (657-676). Reforms of this particular rite, best known as the Visigothic or Mozarabic rite but now normally indicated as the Old Hispanic rite, took place in the course of the eleventh century, mainly under the influence of Cluniac monks. ${ }^{32}$ The Sacramentary of Vich, the third relevant source in Moeller's collections, is an early example of this development. The Old Hispanic rite was officially brought to an end during the papacy of Gregory VII (1073-1085) with the active support of the Spanish kings, ${ }^{33}$ although in a number of chapels the old rite continued to be celebrated. ${ }^{34}$ The Mass for Thomas in the Sacramentary of Vich illustrates the changes procured by the eleventh-century reforms: the long elaborations on feasts and saints that characterise the older tradition, as is visible in the Mass orders for Thomas in London British Library Add. 30844 and Madrid Biblioteca Nacional 494, were removed from the prayers in the younger sacramentary. The older Mass orders are of special interest to the present investigation because of their elaborate use of apocryphal material, as will become clear from the following analysis.

$30<$ http://www.bl.uk/manuscripts/FullDisplay.aspx?ref=Add_MS_30844>, accessed 31 July 2015. The Mass for Thomas is edited in Liber Mozarabicus sacramentorum, ed. Férotin, 608-14.

31 Liber missarum de Toledo, ed. J. Janini (Toledo: Instituto de estudios visigótico-mozárabes, 1983), vol. 2, xxiv. The Mass for Thomas is edited in the same volume 321-24.

32 A.A. King, Liturgies of the Primatial Sees (London-New York: Longmans, Green, 1957), 50315; Santiago, Saint-Denis and Saint Peter. The Reception of the Roman Liturgy in Léon-Castille in 1080, ed. B.F. Reilly (New York: Fordham University Press, 1985); L. Vones, "The Substitution of the Hispanic Liturgy by the Roman Rite in the Kingdoms of the Iberian Peninsula," in Hispania Vetus. Musical-Liturgical Manuscripts. From Visigothic Origins to the Franco-Roman Transition ( 9 th-12th Centuries), ed. S. Zapke (Bilbao: Fundación BBVA, 2007), 43-95, who describes the process as a gradual development that has its roots already in the Carolingian ninth century. Further bibliography in S. Boynton, "Restoration or Invention? Archbishop Cisneros and the Mozarabic Rite in Toledo," Yale Journal of Music and Religion 1 (2015): 5-30. On terminology, see A. Ward and C. Johnson, 'Présentation', in Liber mozarabicus sacramentorum, ed. Férotin, 10-11.

33 Ward and Johnson, 'Présentation', 10.

34 Boynton, “Restoration or Invention?', 5-6. 
The Liber Misticus contains both Offices and Masses, including a Mass for

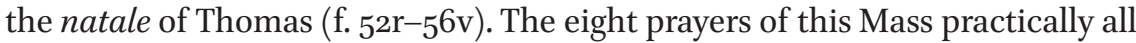
contain references to the life and deeds of Thomas as narrated in the apocryphal Acts. The prayers do not, however, concentrate on Thomas' preaching of an ascetic way of life in which the rejection of marriage is central, and which was the direct cause of Thomas' martyrdom. Even if the prayers address the theme of abstinence from marital life, they do not mention Mygdonia, the protagonist in the third section of the Virtutes Thomae, but instead mention other highborn women, such as Syntice, Mygdonia's friend, or Pelagia, the bride in the first section of the Virtutes Thomae. ${ }^{35}$

Themes other than marital chastity take a much more prominent position in the prayers. Central is the narrative of Thomas' assignment to build a palace for King Gundafor and its spiritual meaning. In the apocryphal Acts, Thomas exploits the power vacuum created by Gundafor's absence to create a two-fold transformation of the king's cities and subjects. First, he transforms the civitates he visits during his travels through India ${ }^{36}$ into essentially Christian communities by converting their inhabitants through his preaching, his charity, and through Baptism, ordaining clergy, and the building of churches. ${ }^{37}$ In the second place, he shifts the focus of the citizens, first and foremost of their rulers

35 See the summary above. The mentioning of the names Syntice (Synticitia) in the prayer Post sanctus (Liber Mozarabicus sacramentorum, 1341) and of Pelagia and Dyonisius (Pelagia's groom) in the first prayer (Missa, Liber Mozarabicus sacramentorum, 1336) indicates that these prayers are based on the Passio (BHL 8136), not the Miracula (BHL 8140) where these details are not found.

36 The Passio Thomae frequently mentions the word civitas as Thomas' destination; sometimes a city is mentioned by name. So c. 6: tenuerunt civitatem Andronopolim, where the wedding of Dionysius and Pelagia is celebrated: all (omnes) must attend the wedding, civis et peregrinus. c. 16 mentions Hieroforus: Cum autem esset Hieroforum apostolus Indiae civitatem ingressus as Gundafor's city where Thomas is supposed to build the palace. Nameless cities are further mentioned in c. 17: Apostolus autem coepit circuire per vicinas civitates (see further footnote 37); c. 21: Ecce et provinciae vestrae et civitates vestrae ecclesiis plenae sunt (see above footnote 6); c. 23: de longinquis et proximis civitatibus venientes, the people come from far and wide to venerate Thomas whom they consider to be a god.

37 The shortest summary of Thomas' activity in answer to Gundafor's assignment is given in Passio Thomae, c. 17: Apostolus autem coepit circuire per vicinas civitates, praedicare verbum dei et donare pauperibus, baptizare credentes et abundanter donare egenis. Unde factum est ut innumerabilem populum domino acquireret. Ordinavit autem cleros, ecclesias fabricavit et per totum biennium quod absens rex Gundaforus fuit firmavit ecclesias. Zelzer, Die alten lateinischen Thomasakten, 13-14.

Sanctifying texts, transforming rituals : Encounters in liturgical studies. (2017). Retrieved from http://ebookcentral.proquest.com Created from uunl on 2019-07-26 04:43:15. 
rex Gundafor and his brother Gad, from the present life to the life hereafter. ${ }^{38}$ The people as well, if they want to participate in eternal life, are required to accept the Christian doctrine of Trinitarian belief ${ }^{39}$ in order to bear its fruits (fructum): good faith (bene credatis) and a Christian way of life. This life is summarised in twelve virtues (virtutes) that entail the abstinence from vices such as fornication, avarice and gluttony and the perseverance in Christian virtues, such as fasting, good works, hospitality and obedience to God's will and loving one's neighbour and enemy alike. ${ }^{40}$

The two-fold transformation of India's civitates is clearly recognisable in the Mass order of the Liber misticus, as the following examples will reveal.

(1) Alia. ${ }^{41}$ The prayer qualifies Thomas, sent to India in order to construct a spiritual building (ad construendum spiritale edificium), as the foundation of faith (fundamentum fidei) for the community that commemorates his feastday, and underlines the contrast between the terrestrial palace that the king had asked for and the building that was the result:

Truly, your holy man, when he was sent there, did not erect a building for the extravagance of the transitory ${ }^{42}$ world to enjoy, but for the profits of the souls of the faithful to be perpetually pursued. [And he did not build such a work] that this ruinous antiquity of the terrestrial world would

38 Summarised most concretely by Thomas when he points Gundafor and Gad to the uselessness of earthly riches after death in Passio Thomae, c. 22: Si ergo de caelestibus divitiis et regnis et palatiis agere vultis, divitiae vestrae vos antecedere possunt, sequi vero exeuntes de mundo omnino non possunt. Permittite ergo illas servire tribulantibus, egentibus, peregrinis, afflictis, necessitatem patientibus, infirmantibus, debita habentibus, viduis, orfanis, esurientibus, sitientibus, nuditatem patientibus atque variis casibus subiacentibus; et estote securi quoniam ibi vobis centuplicantur vestrae divitiae ubi nullus finis decurrit. Zelzer, Die alten lateinischen Thomasakten, 17.

39 Si volueritis ad vitam aeternam pertingere, primo omnium credite in deum (...) et in filium (...) Iesum Christum et in spiritum sanctum. Passio Thomae, c. 27, Zelzer, Die alten lateinischen Thomasakten, 20-21.

40 For the details of the twelve fruits or virtutes, see Passio Thomae, c. 30, Zelzer, Die alten lateinischen Thomasakten, 22-23. The enumeration deviates from Gal. 5, 22-23, the traditional list of nine fruits of the Spirit, later in the Middle Ages extended to twelve, see e.g. the sermon for Pentecost of Antonius of Padua (1195-1231), in Sermones dominicales et festivi, ed. B. Costa et al. (Padova: Edizioni Messagero, 1979), vol. 1, 500.

41 Liber Mozarabicus sacramentorum, 1337, ed. Férotin, 6o9-10.

42 labentis (seculi): the word is only attested in Blaise's Medieval Dictionary as used by Walafrid Strabo: labentia gaudia mundi. A. Blaise, Lexicon Latinitatis Medii Aevi (Turnhout: Brepols, 1974), s.v. labens. 
once destroy a palace erected with walls (lateribus), but he completed from precious stones for all who believe in you a habitation in the heavenly kingdom which will last happily without end. ${ }^{43}$

The prayer highlights the palace as the most important theme in the story about Thomas. In doing so, the ownership of the palace is modified in a subtle way. No longer is the palace meant for Gundafor or his brother in exchange for their conversion and albeit retroactive charity. The destination of the palace becomes much broader in this prayer, functioning as a celestial dwelling for all believers (tibi credentibus peregit habitaculum feliciter sine fine mansurum). We encounter this modification as a leitmotiv in the Spanish prayers and as the core of the spiritual understanding of the story of Thomas in the early medieval region from which these prayers stem.

(2) Ad pacem. The prayer that accompanies the exchange of the kiss of peace also emphasises the idea that the celestial palace for Gundafor is built as a dwelling place for the people. ${ }^{44}$ The prayer connects this heavenly dwelling with a Christian way of life and prays for the faithful to become, during their life on earth, "practitioners of peace and charity" (cultores effici mereamur pacis et karitatis), in order to obtain the life hereafter.

(3) Inlatio. ${ }^{45}$ The lengthy prayer that precedes the narrative of institution in the Old Hispanic rite gives no apocryphal details. It does, however, continue the theme of access to celestial life in the first part. This part commemorates Christ's saving work, contrasting Christ's humiliation with the elevation of the faithful. Christ went into the depths of hell to raise the faithful to the kingdom of heaven; he tasted the bitterness of gall to grant the faithful the joy of the sweetness of eternal life; and he accepted a crown of thorns in order to crown the faithful with a diadema.

43 Liber Mozarabicus sacramentorum, 1337: Et sicut eum Indorum apostolum dedisti ad construendum spiritale edificium: ita eodem suffragante, cordibus nostris augeas fundamentum fidei. Non enim hic sanctus tuus utique missus tale opus erexit, ubi labentis seculi frueretur luxuria; sed ubi credentium animarum iugiter conquererentur lucra. Hec ut ruinosa uetustas seculi terrenis lateribus erectum quandoque dirueret palatium; sed celesti in regno ex lapidibus pretiosis tibi credentibus peregit habitaculum feliciter sine fine mansurum, ed. Férotin, 609.

44 Liber Mozarabicus sacramentorum, 1339: ... qui Gundoforo regi per boni operis exercitium in regno tuo ad habitantium populorum preparauit palatium, ed. Férotin, 611.

45 Liber Mozarabicus sacramentorum, 1340, ed. Férotin, 611-12. 
(4) Post Sanctus. Like the inlatio, the prayer Post Sanctus provides the Christological framework in which Thomas is placed as Christ's follower and imitator. The prayer opens with a praise of Christ's saving work by which he opened the kingdom of heaven (polorum regna) to the faithful, "in order to make us there co-heirs of his life, who wanted here to participate in our death". ${ }^{46}$ Thus, this text makes explicit that the faithful have a part in the celestial kingdom through inheritance (cf. Rom. 8, 17). In the original text in Paul's letter to the Romans, Christ's sonship is central, and those who believe in Christ share in that inheritance as adopted children (filii adoptionis). ${ }^{47}$ In the liturgical prayer, the direction is different: the faithful participate in Christ's inheritance (of eternity) because Christ has shared in their mortality. The concept of the joint heir occurs frequently in the work of Hildefonsus of Toledo (c. 607-667), e.g. in his treatise on baptism ${ }^{48}$ and in his treatise De itinere desertis. In the latter work, the use of the word coheredes corresponds even more to the transformation of communal life here and hereafter as it is described in the Acts of Thomas and commemorated in the liturgical prayers. Here Hildefonsus describes the process of Christianisation as equal to the exodus from Egypt, ultimately leading to the entrance in "the land of the living (terram uiuentium regionis), where the baptised will be co-heirs of Christ and sons of the kingdom". ${ }^{49}$ The prayers as well as the treatises of Hildefonsus reflect the importance of membership in the heavenly realm: the celestial palace that Thomas builds for Gundafor

46 Liber Mozarabicus sacramentorum 1341: Adscensione sua in celis polorum regna nobis clementer aperuit: ut illic nos coheredes faceret uite sue, qui hic participes fieri uoluit mortis nostre, ed. Férotin, 612-13.

47 For a recent commentary on this passage in the Pauline epistle, see A.J. Hultgren, Paul's Letter to the Romans. A Commentary (Grand Rapids, MI-Cambridge: Eerdmans, 2011), 316.

48 ipse primogenitus consecuturis fratribus, quos in adoptionem filiorum Dei uocauit, quos comparticipes et coheredes suos esse dignatus est. Hildefonsus of Toledo, De cognitione baptismi, c. 50, CCSL 114A, ed. V. Yarza Urquiola (Turnhout: Brepols, 2007), 382.

49 Hildefonsus of Toledo, De itinere deserti, c. 6: Itaque post liberationem Aegyptiae seruitutis, post egressionem Aegyptiae mansionis, post insecutionem Aegyptii exercitus, post transitum saeuientis maris, post interitum Pharaonis, post excidium Aegyptiae multitudinis, post gratulationem saluationis Israhelitarum, post canticum gloriae Dei, id est postquam reliquimus mundum, postquam conuersi sumus ad Deum, post insecutionem daemonum, post mersionem baptismatis, post priuationem diabolicae potestatis, post dimersionem peccatorum, post exultationem indultae salutis, post gloriam et diuinae laudationis hymnum, considerandum est quo ducimur et per qua ducimur, reminiscentes nos adtrahi et uocari per solam gratiam conditoris ad terram repromissionis, scilicet terram uiuentium regionis, in qua erimus coheredes Christi et filii regni, ed. Yarza Urquiola, 440. The inlatio in the Mass for Thomas as transmitted in Madrid Biblioteca Nacional 494 (see below) also paraphrases Rom. 8, 17 .

Sanctifying texts, transforming rituals : Encounters in liturgical studies. (2017). Retrieved from http://ebookcentral.proquest.com Created from uunl on 2019-07-26 04:43:15. 
transforms into the participation in the heavenly reward that all believers were promised.

The prayers for Thomas in Madrid Biblioteca Nacional 494 are of a different, more restrained character than those in the Liber misticus..$^{50}$ Details from the apocryphal Acts, such as names or specific references to the narrative, are not included. Nonetheless, the prayers show references to the two-fold transformation of the cities of India and apply that transformation to the faithful who commemorate Thomas in a similar way as the Liber misticus did, particularly in the prayer Post nomina:

God, you who appoint your excellent Thomas as an architect and do not reject it as unworthy to walk around the slave market: form us from the living stones from which the vision of heavenly peace is restored, ${ }^{51}$ so that we, brightly shining ${ }^{52}$ with chastity, are equal in the union (participatione) of the saints who have already gone before us in the Lord. That you, who have descended on behalf of sinners from that lofty throne to

50 Liber missarum de Toledo, 1518, ed. Janini, 321-24. Moeller traces all prayers of this Mass to Madrid Biblioteca Nacional 494 (is his siglum 495 an error? He refers to Janini's edition in Liber Missarum de Toledo), but the status of the inlatio is unclear, whence the prayer is left out of the following analysis. According to Moeller, who gives this text in Corpus praefationum, no. 516 (Moeller, Corpus praefationum A: textus $(A-P), 142$ ), the prayer is only found in the Missale Mixtum (see Moeller's source indication in Corpus praefationum B: apparatus $(A-P), 249)$, an early modern composition commissioned by archbishop Cisneros of Toledo (1495-1517) and executed by Alfonso Ortiz in 1500 (Boynton, "Restoration or Invention?', 6). Janini himself indicates the Mass for Thomas in the Missale Mixtum 178-82 as 'nueva' (new) (J. Janini, "Misas Mozárabes recompuestas por Ortiz," Hispania sacra 34 (1982): 162), while at the same time the prayers he edits in Liber missarum de Toledo are presented as both stemming from the twelfth-century quire in Madrid Biblioteca Nacional 494 and occurring in Ortiz' Missale Mixtum as 178-82. The inlatio itself is interesting because of references to the Passio Thomae in detail (the names of Syntice and other converts are given, as well as the story of the Hebrew girl present at the wedding of Pelagia), and because it includes the theme of Baptism that makes the newly converted adopted children: In cuius [sc. Christi] Thomas apostolus tuus populos conuertit indanicos a pristino cultu erroris, et in filios adoptauit sacro gurgite tinctionis (Liber missarum de Toledo, 1518, vol. II, 322).

$5^{1} \quad$ Both effice and instauratur also have the meaning to perform'. L.F. Stelten, Dictionary of Ecclesiastical Latin (Peabody, MA: Hendrickson, 1995), s.v. efficio, instauro.

$5^{2}$ renitentes, from reniteo; A. Blaise, Dictionnaire latin-français des auteurs chrétiens (Turnhout: Brepols, 1954), s.v. reniteo.

Sanctifying texts, transforming rituals : Encounters in liturgical studies. (2017). Retrieved from http://ebookcentral.proquest.com Created from uunl on 2019-07-26 04:43:15. 
earth, may favourably attend our prayers, while you grant eternal rest to all deceased faithful. ${ }^{53}$

The prayer introduces Thomas as the architect appointed by God, whose building work is understood here in the same vein as the story of the Virtutes expresses: the result of Thomas' mission is not a palace in stone but a Christian community whose members are built of peace. Their way of life, in this prayer primarily summarised in the word castitas (candore castitatis nivea renitentes), grants them access to participation in the community of saints in heaven. Thus, the inhabitants of Gundafor's provinciae et civitates are models for the commemorating communities of early medieval Spain, who combine the two main themes of the Acts of Thomas into one prayer to become part of the community of saints in the life to come.

\section{Conclusion}

Insofar as the Latin liturgical commemoration of the apostle Thomas is based on the apocryphal Acts, the theme of Thomas building a 'palace' for rex Gundafor is selected most frequently and developed most elaborately. While the episode as it is included in the Virtutes Thomae narrates the transformation process by which the inhabitants of India's terrestrial cities become dwellers in the heavenly realm, its incorporation in the liturgical prayers is an example of another transformation, viz. with regard to the possessors of the celestial palace. No longer is the palace a private dwelling place for its patron (rex Gundafor) upon his conversion to Christianity; now it becomes a celestial mansion for all believers. This transformation, which takes place in the liturgical texts of the Old Hispanic rite, remains visible also in later periods of medieval Christianity. The early thirteenth-century window dedicated to the apostle Thomas in Chartres cathedral depicts Gundafor's palace as an architectural composition that blessed souls (naked figures) occupy. They are crowned as kings, which probably refers to 'the crown of life' in Apo 2, 10 (coronam vitae) rather than to Gundafor's kingship. According to Colette Deremble, the window depicts the

53 Deus, qui tuum Thomam egregium paedicis architectum et in foro non dedignas ambulare venalium, tu nos ex illis lapidibus effice vivis, a quibus illa visio pacis instauratur caelestis, qualiter, candore castitatis nivea renitentes, sanctorum, qui nos in domino iam praecesserunt, possimus esse in participatione aequales, ut, qui pro peccatoribus ab illa sublimi sede descendisti ad terram, precibus nostris placatus assistas, omnibus requiem defunctis fidelibus praestans. Text according to Corpus orationum III, 2143, 198.

Sanctifying texts, transforming rituals : Encounters in liturgical studies. (2017). Retrieved from http://ebookcentral.proquest.com Created from uunl on 2019-07-26 04:43:15. 


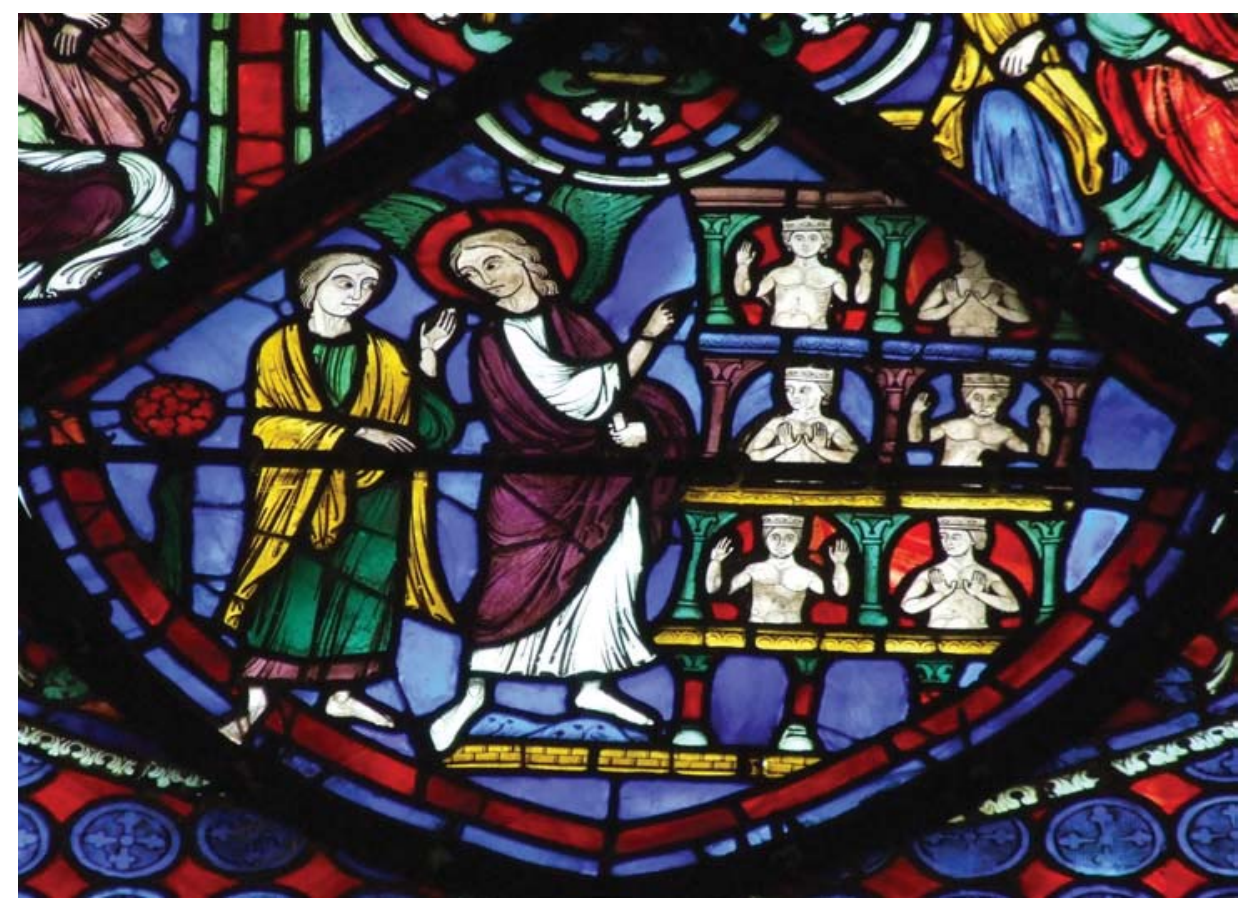

FIGURE 5.1 The celestial palace is shown to Gad. Chartres Cathedral. PHOTOGRAPH: JAAP TUIJN.

celestial palace as 'la Jérusalem céleste où les âmes en prières, pierres vivantes de l'édifice, rendent grâces à Dieu'.54 Thus, the medieval liturgical and visual representation of the Acts of Thomas completes the process of transformation that the textual tradition has started. The inhabitants of the civitates Indorum, these exotic cities in faraway India described in the ancient apocrypha, speak centuries later to Christian communities in the Iberian Peninsula and in the

54 C. Deremble and J.-P. Deremble, Vitraux de Chartres (Paris: Éditions Zodiaque, 2003), $15^{2}$. I am grateful to Gerard Rouwhorst, who put me on the track of the visual representations of the apocryphal Acts in medieval stained glass windows. In addition, I thank Dr. Henry Schilb for guiding my search on this topic in the Princeton Index of Christian Art at Princeton University, autumn 2015, as well as Marilyn Aronberg Lavin and Marvin Lavin for sharing their thoughts on this image during conversations in the autumn of 2015. Marilyn Lavin pointed out the symmetry of the crowned figures, expressing by the gestures of their hands both prayer (orante) and praise (acclamatio). An image of the heavenly Jerusalem that is like the Chartres panel in depicting saved persons in a multistorey architectural structure is British Library Add ms. 42555, f. 79v ('The Abingdon Apocalypse', dated c. 1275) <http://www.bl.uk/manuscripts/Viewer.aspx?ref=add_ms_42555_fsoo1ar> consulted 19 October 2015 . 
heart of France about their double belonging: living a Christian way of life on earth according to the precepts of Christian doctrine in order to attain membership in the celestial regnum.

\section{Bibliography}

\section{Primary Sources}

Antonius of Padua (1195-1231), Sermones dominicales et festivi. Edited by B. Costa et al. Padova: Edizioni Messagero, 1979.

Hildefonsus of Toledo, De cognitione baptismi, CCSL 114A. Edited by V. Yarza Urquiola. Turnhout: Brepols, 2007.

Hildefonsus of Toledo, De itinere deserti, CCSL 114A. Edited by V. Yarza Urquiola. Turnhout: Brepols, 2007.

Irish Palimpsest Sacramentary. In Das irische Palimpsestsakramentar im CLM 14429 der Staatsbibliothek München. Edited by A. Dold and L. Eizenhöfer. Beuron: Beuroner Kunstverlag, 1964.

Liber missarum de Toledo. Edited by J. Janini. Toledo: Instituto de estudios visigóticomozárabes, 1983 .

Liber Mozarabicus sacramentorum. Edited by M. Férotin. Paris: Firmin-Didot, 1912; repr. by A. Ward and C. Johnson, Rome: CLV Edizioni liturgiche, 1995.

Liber pontificalis I, MGH GPR I. Edited by Th. Mommsen. Berlin: Weidemann, 1898.

Liber sacramentorum Augustodunensis, CCSL 159B. Edited by O. Heiming. Turnhout: Brepols, 1984.

Liber sacramentorum Engolismensis, CCSL 159C. Edited by P. Saint Roch. Turnhout: Brepols, 1987 .

Liber sacramentorum Gellonensis, CCsL 159. Edited by A. Dumas and J. Deshusses. Turnhout: Brepols, 1981.

Liber sacramentorum Romanae aeclesiae ordinis anni circuli (Cod. Vat. Reg. lat. 316/Paris Bibl. Nat. 7193, 41/56) (Sacramentarium Gelasianum). Edited by L.C. Mohlberg. Rome: Herder, 1968.

De miraculis beati Thomae apostoli. In Die alten lateinischen Thomasakten. Edited by K. Zelzer, 43-77. Berlin: Akademie-Verlag, 1977.

Missale Gothicum. In Missale Gothicume codice vaticano reginensilatino 317 editum, CCSL 159D. Edited by E. Rose. Turnhout: Brepols, 2005.

Passio Thomae (BHL 8136). In Die alten lateinischen Thomasakten. Edited by K. Zelzer, 1-42. Berlin: Akademie-Verlag, 1977.

Sacramentarium Bergomense. In Sacramentarium Bergomense: manoscritto del secolo IX della Biblioteca di S. Alessandro in Colonna in Bergamo. Edited by A. Paredi. Bergamo: Monumenta Bergomensia, 1962.

Sanctifying texts, transforming rituals : Encounters in liturgical studies. (2017). Retrieved from http://ebookcentral.proquest.com Created from uunl on 2019-07-26 04:43:15 
Sacramentarium Gregorianum Hadrianum. In Le sacramentaire grégorien. Ses principales formes d'après les plus anciens manuscrits, vol 1: Le sacramentaire, le supplément d'Aniane. Edited by J. Deshusses. Fribourg: Éditions universitaires Fribourg Suisse, 1971.

Victricius of Rouen, De laude sanctorum, CCSL 64. Edited by J. Mulders and R. Demeulenaere. Turnhout: Brepols, 1985 .

\section{Secondary Sources}

Blaise, A. Dictionnaire latin-français des auteurs chrétiens. Turnhout: Brepols, 1954.

Blaise, A. Lexicon Latinitatis Medii Aevi. Turnhout: Brepols, 1974.

Bovon, F. "La vie des apôtres. Traditions bibliques et narrations apocryphes." In Actes apocryphes des apôtres. Edited by F. Bovon et al., 141-158. Geneva: Labor et Fides, 1981.

Bovon, F., and P. Geoltrain, ed. Écrits apocrpyhes chrétiens I. Paris: Gallimard, 1997.

Boynton, S. "Restoration or Invention? Archbishop Cisneros and the Mozarabic Rite in Toledo." Yale Journal of Music and Religion 1 (2015): 5-30.

Brock, S. "Incovations to/for the Holy Spirit in Syriac Liturgical Texts: Some Comparative Approaches." In Comparative Liturgy Fifty Years after Anton Baumstark (1872-1948). Edited by R.T. Taft and G. Winkler, 377-406. Rome: Pontificio Istituto Orientale, 2001.

Corpus orationum, CCSL 160-16oM. Edited by E. Moeller et al. Turnhout: Brepols, 1992-2004.

Corpus praefationum, CCSL 161, 161A-161D. Edited by E. Moeller. Turnhout: Brepols.

Corpus benedictionum pontificalium, CCSL 162, 162A-162C. Edited by E. Moeller. Turnhout: Brepols, 1971-79.

Crehan, J.H. "Eucharistic Epiklesis: New Evidence and a New Theory." Theological Studies 41 (1980): 698-712.

Deremble, C., and J.-P. Deremble, Vitraux de Chartres. Paris: Éditions Zodiaque, 2003.

Ewig, E. "Die Kathedralpatrozinien im römischen und fränkischen Gallien.” In Spätantikes und fränkisches Gallien. Gesammelte Schriften (1952-1973). Edited by H. Atsma, vol. 2, 260-317. Munich: Artemis Verlag, 1979.

Ewig, E. "Der Petrus- und Apostelkult im spätrömischen und fränkischen Gallien.” In Spätantikes und fränkisches Gallien, vol. II, 318-354.

Ewig, E. "Die Verehrung orientalischer Heiliger im spätrömischen Gallien und im Merowingerreich." In Spätantikes und fränkisches Gallien, vol. II, 393-410.

Hen, Y. The Royal Patronage of Liturgy in Frankish Gaul to the Death of Charles the Bald (877). London: Henry Bradshaw Society, 2001.

Henry, J.K. "The Acts of Thomas as Sacred Text." In Sacra Scriptura. How "Non-Canonical" Texts Functioned in Early Judaism and Early Christianity. Edited by J.H. Charlesworth et al., 152-170. London-New York: Bloomsbury, 2014.

Hultgren, A.J. Paul's Letter to the Romans. A Commentary. Grand Rapids, MI-Cambridge: Eerdmans, 2011. 
Janini, J. “Misas Mozárabes recompuestas por Ortiz." Hispania sacra 34 (1982): 153-163. Johnson, C. "Ritual epicleses in the Greek Acts of Thomas." In The Apocryphal Acts of the Apostles: Harvard Divinity School Studies. Edited by F. Bovon et al., 171-204. Cambridge, MA: Harvard University Center for the Study of World Religions, 1999.

Kennedy, V.L. The Saints of the Canon of the Mass. Città del Vaticano: Pontificio Istituto di Archeologia Cristiana, 1938.

King, A.A. Liturgies of the Primatial Sees. London: Longmans-Green, 1957.

Myers, S. "Antecedents of the Feminine Imagery of the Spirit in the Acts of Thomas." Apocrypha 26 (2015): 103-118.

Reilly, B.F., ed. Santiago, Saint-Denis and Saint Peter. The Reception of the Roman Liturgy in Léon-Castille in 1080. New York: Fordham University Press, 1985.

Rose, E. Ritual Memory. The Apocryphal Acts and Liturgical Commemoration in the Early Medieval West (c. 500-1215), Mittelalterliche Studien und Texte 40. Leiden: Brill, 2009.

Rose, E. "Abdias scriptor vitarum sanctorum apostolorum? The "Collection of PseudoAbdias" reconsidered." Revue d'histoire des textes n.s. 8 (2013): 227-268.

Rose, E. “Virtutes apostolorum: Origin, Aim, and Use.” Traditio 68 (2013): 57-96.

Rouwhorst, G.A.M. "Hymns and Prayers in the Apocryphal Acts of Thomas." In Literature or Liturgy? Early Christian Hymns and Prayers in their Literary and Liturgical Context in Antiquity. Edited by C. Leonhard and H. Löhr, 195-212. Tübingen: Mohr Siebeck, 2014.

Rouwhorst, G.A.M. "Faire mémoire par un geste: La fraction de pain." In Faire mémoire. L'anamnèse dans la liturgie, Conférences Saint-Serge LVIe Semaine d'Études liturgiques. Paris, 29 juin-2 juillet, 2009. Edited by A. Lossky and M. Sodi, 75-86. Città del Vaticano: Libreria editrice Vaticana, 2011.

Rouwhorst, G.A.M. “L'usage et le non-usage du vin.” In Rites de communion, Conférences Saint-Serge Lve Semaine d'Études liturgiques. Paris, 23-26 juin, 2008. Edited by A. Lossky and M. Sodi, 229-241. Città del Vaticano: Libreria editrice Vaticana, 2010.

Rouwhorst, G.A.M. "Die Rolle des heiligen Geistes in der Eucharistie und der Taufe im frühsyrischen Christentum." In Liturgie und Trinität. Edited by B. Groen and B. Kranemann, 161-184. Freiburg i.B.: Herder, 2008.

Rouwhorst, G.A.M. “La célébration de l'eucharistie selon les Actes de Thomas." In Omnes circumadstantes. Contributions towards a History of the Role of the People in the Liturgy. Edited by Ch. Caspers and M. Schneiders, 51-77. Kampen: Kok, 1990.

De Santos Otero, A. "Jüngere Apostelakten." In Neutestamentliche Apokryphen in deutscher Übersetzung. 6. Auflage der von Edgar Hennecke begründeten Sammlung, vol 2: Apostolisches, Apokalyptisches und Verwandtes. Edited by W. Schneemelcher, 410-11. Tübingen: Mohr Siebeck, 1997.

Stelten, L.F. Dictionary of Ecclesiastical Latin. Peabody, MA: Hendrickson, 1995.

Vogel, C. Medieval Liturgy. An Introduction to the Sources, translated by W. Storey and N. Rasmussen. Washington DC: The Pastoral Press, 1986.

Sanctifying texts, transforming rituals : Encounters in liturgical studies. (2017). Retrieved from http://ebookcentral.proquest.com Created from uunl on 2019-07-26 04:43:15. 
Vones, L. "The Substitution of the Hispanic Liturgy by the Roman Rite in the Kingdoms of the Iberian Peninsula." In Hispania Vetus. Musical-Liturgical Manuscripts. From Visigothic Origins to the Franco-Roman Transition (9th-12th Centuries). Edited by S. Zapke, 43-95. Bilbao: Fundación BBVA, 2007.

Ward A., and C. Johnson, "Présentation." In Le Liber mozarabicus sacramentorum et les manuscrits mozarabes. Edited by M. Férotin. Paris: Firmin-Didot, 1912; repr. by A. Ward and C. Johnson, Rome: CLV Edizioni liturgiche, 1995. 